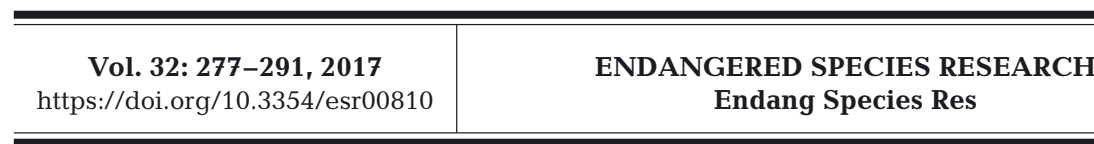

Contribution to the Theme Section 'Biology and ecology of sawfishes'

\title{
Sawfishes in Papua New Guinea: a preliminary investigation into their status and level of exploitation
}

\author{
William T. White ${ }^{1, *}$, Sharon A. Appleyard ${ }^{1}$, Peter M. Kyne ${ }^{2}$, Ralph R. Mana ${ }^{3}$ \\ ${ }^{1}$ CSIRO Australian National Fish Collection, National Research Collections Australia, Hobart, Tasmania 7000, Australia \\ ${ }^{2}$ Research Institute for the Environment and Livelihoods, Charles Darwin University, Darwin, Northern Territory 0909 , \\ Australia \\ ${ }^{3}$ School of Natural and Physical Sciences, University of Papua New Guinea, National Capital District, 131, \\ Papua New Guinea
}

\begin{abstract}
The status of sawfishes (family Pristidae), and indeed most sharks and rays, in Papua New Guinea (PNG) is largely unknown due to the paucity of detailed catch and observational records available, both historic and contemporary. This paper provides the first comprehensive review of the published and unpublished literature on sawfish records in PNG. It also collates information for all sawfish specimens in the holdings of museum and fisheries collections, dating back to the late 1800s. Opportunistic sampling during a shark and ray biodiversity project in PNG has resulted in contemporary records for all 4 sawfish species known to occur in the region (i.e. Anoxypristis cuspidata, Pristis clavata, P. pristis and P. zijsron) and identification of suitable habitat for the species across PNG. A review of the literature shows that declines in sawfish populations have occurred in a number of locations. Detailed surveys of the key areas highlighted in this study are urgently required to assess the current status of sawfish in PNG. This information is crucial for developing a global strategy for sawfish conservation and fisheries management, given the apparent persistence of all 4 Indo-Pacific species in PNG.
\end{abstract}

KEY WORDS: Pristidae $\cdot$ Sawfish $\cdot$ Fisheries $\cdot$ Research needs

\section{INTRODUCTION}

Papua New Guinea (PNG) lies within the megadiverse region of the Indo-West Pacific known as the Coral Triangle. Elasmobranchs (sharks and rays) are key biota contributing to biodiversity in the Coral Triangle, but our understanding of the fauna of PNG is still in its infancy. Most of our knowledge of sharks and rays in PNG comes from historical records from small-scale biodiversity surveys and expedition reports (e.g. Herre 1936, Roberts 1978, Allen \& Coates 1990) and there is no detailed biodiversity information. It is thus difficult to assess the current status of the sharks and rays present in PNG, and how they

${ }^{*}$ Corresponding author: william.white@csiro.au are impacted by various anthropogenic activities such as mining, pollution and fishing.

An example of the paucity of information available for sharks and rays in PNG was the recent 'rediscovery' of 2 species of river sharks (Glyphis spp.) in the Western Province of PNG (White et al. 2015). These species, which are listed as Endangered and Critically Endangered on the International Union for Conservation of Nature (IUCN) Red List of Threatened Species (IUCN 2016), had not been recorded from PNG since the 1960s and 1970s. However, during a short field survey to Daru and Katatai in PNG in October 2014, both species were confirmed in the catches of local gillnet fishers, with the fishers report-

(C) The authors 2017. Open Access under Creative Commons by Attribution Licence. Use, distribution and reproduction are unrestricted. Authors and original publication must be credited. 
ing that they are regularly caught in low numbers throughout the year at those locations (White et al. 2015). That finding highlighted that the 'rediscovery' reflected a lack of information available for sharks in PNG, rather than the outcome of a directed study to find an elusive and rare species.

During recent surveys of the Western Province in 2014, which aimed to broadly survey sharks and rays, another key finding from the fisheries catches were records of sawfishes. Sawfish are considered the most threatened family of elasmobranchs, with all species listed as Critically Endangered or Endangered on the IUCN Red List (Dulvy et al. 2014, IUCN 2016). It has been suggested by Dulvy et al. (2016) that sawfish are now extinct in at least 20 countries, with the dwarf sawfish Pristis clavata considered Possibly Extinct in PNG. The status of sawfish in PNG is largely unknown, both in a historical and contemporary sense, due to the paucity of detailed information on shark and ray catches and observations in PNG. New Guinea has, however, been suggested as possibly being a regionally significant area for sawfishes, and the need to determine local status has been previously highlighted (Kyne \& Simpfendorfer 2014).

The area surveyed in Western Province near the mouth of the Fly River is prime sawfish habitat, consisting of mangrove-lined shores with numerous freshwater outflows and high turbidity (Last \& Stevens 2009). However, it was surprising to find records of all 4 sawfish species known to occur in this region from the fisheries catches in only a $1 \mathrm{wk}$ survey. The 4 species known to occur in the Australasian region, and more widely the Indo-Pacific, are narrow sawfish Anoxypristis cuspidata, dwarf sawfish Pristis clavata, largetooth sawfish $P$. pristis, and green sawfish $P$. zijsron (Last \& Stevens 2009).

This paper provides a comprehensive review of published and unpublished literature on sawfish records in PNG and holdings in museum and fisheries collections. It also provides data on opportunistic records of sawfish obtained as part of a 4 yr project investigating shark and ray fisheries and biodiversity in PNG.

\section{MATERIALS AND METHODS}

\section{Literature records}

A comprehensive literature review was undertaken, based on unpublished reports and surveys, to find as many records of sawfish in PNG waters as possible. All literature that included a reference to sawfish in PNG are summarised in Table 1. Note that in most cases, the identity of the species could not be accurately determined based on the information available. Identification of species in particular regions is only as accurate as the literature available to researchers.

In PNG, the main faunal guide available to researchers in the 1960s through the 1980s was Munro's (1967) 'Fishes of New Guinea'. In this book, 2 species of sawfish are listed: Pristiopsis microdon and $P$. leichhardti, both of which are synonyms of Pristis pristis. Thus, the 3 other sawfish species were not represented in this guide. As a result, subsequent literature typically only makes reference to these 2 species, with most literature sources (that provide a species name) only listing $P$. microdon. A number of literature sources simply list the common name of 'sawfish' or 'sawshark', which are all considered to refer to pristids since no species of sawsharks (family Pristiophoridae) occur in PNG waters. As a result, it is not possible to accurately determine which sawfish species were represented in most of the literature sources. Filewood (1973) provided the first comprehensive key to the sharks and rays occurring in PNG, but this was never published. This key included 3 sawfish species, Platypristis cuspidatus (= Anoxypristis cuspidata), Pristis zijaron (= Pristis zijsron) and $P$. microdon (= P. pristis).

In addition to literature records, attempts were made to contact authors of publications with brief mention of sawfish records, along with those who visit areas of likely sawfish occurrence, e.g. fishing lodges.

\section{Specimen records}

Some literature sources also relate to specimens collected and deposited in museum collections, e.g. Herre (1936), Roberts (1978) and Allen et al. (1992). These records are particularly important in that the species involved can be confirmed. A comprehensive list of all sawfish specimens collected from PNG waters and deposited in the various museum collections around the world was established, and is summarised in Table 2. Where possible, images and measurements were obtained from the specimens (whole or rostrum) to verify their identity. A few records could be accurately linked to a specific literature source. One of the museum collections, the Kanudi Fisheries Research Station (KFRS), deserves a specific mention due to its complicated history. It is estimated that more than $80 \%$ of the shark and ray specimens housed in the original collection in Kanudi 
Table 1. Literature, electronic resource and personal communication records of sawfish from Papua New Guinea. Arranged in chronological order with personal communication records at bottom. Location contains a map reference number (where possible) which refers to localities in Fig. 1. TL: total length; $(-)$ not measured. When species could not be determined, a question mark is used. USNM: United States National Museum

\begin{tabular}{|c|c|c|c|c|}
\hline Source & $\begin{array}{l}\text { Location } \\
\text { [map reference] }\end{array}$ & Notes & $\begin{array}{l}\text { Size } \\
(\mathrm{TL} ; \mathrm{mm})\end{array}$ & Species \\
\hline Herre (1936) & Korogu, Sepik River [45] & $\begin{array}{l}\text { Pristis perotteti common in Sepik, very well knowı } \\
\text { many rostra seen (CAS SU } 41013 \text { and } 41014 \text { ) }\end{array}$ & $v \mathrm{n}$ & Pristis pristis \\
\hline Munro (1958) & Korogu, Sepik River [45] & Pristis microdon based on Herre (1936) records & - & P. pristis \\
\hline Munro (1964) & $\begin{array}{l}\text { Northern and southern } \\
\text { New Guinea }\end{array}$ & $\begin{array}{l}\text { Only } 2 \text { sawfish treated in guide: Pristiopsis } \\
\text { leichhardti (southern) and P. microdon (northern) }\end{array}$ & n) & P. pristis \\
\hline Hinton (1967) & Kapogere, Kemp Welch River [38] & $\begin{array}{l}\text { Gillnet catch (8 Sep 1967): } 1 \text { P. microdon } \\
\text { caught in clear water }\end{array}$ & 967 & $?$ \\
\hline \multirow[t]{2}{*}{ Munro (1967) } & $\begin{array}{l}\text { Laloki River [35] and other } \\
\text { southern rivers }\end{array}$ & P. leichhardti & - & P. pristis \\
\hline & Sepik River [44-46] & P. microdon & - & P. pristis \\
\hline Glucksman (1969) & $\begin{array}{l}\text { Baboa mission, Lake Murray } \\
\text { [8 or } 9]\end{array}$ & $\begin{array}{l}\text { Gillnet catch (28 Nov 1969): a Pristlepis microdon } \\
\text { caught }\end{array}$ & - & P. pristis \\
\hline Aufenanger (1970) & Sepik River [44-46] & $\begin{array}{l}\text { 'Occasionally even huge saw fishes and sharks } \\
\text { swim up and down this great watercourse' }\end{array}$ & - & $?$ \\
\hline $\begin{array}{l}\text { Rapson \& McIntosh } \\
\text { (1971) }\end{array}$ & $\begin{array}{l}\text { Iokea to Orokolo Bay, } \\
\text { Gulf of Papua [31] }\end{array}$ & $\begin{array}{l}\text { Sawfish recorded in prawn trawl surveys } \\
\text { in Feb } 1963\end{array}$ & - & $?$ \\
\hline $\begin{array}{l}\text { Dept of Agriculture, } \\
\text { Stock and }\end{array}$ & $\begin{array}{l}\text { New Bosnean Camp, } \\
\text { Ramu River [43] }\end{array}$ & Gillnet catch (18 Aug 1972): 1 sawfish & 1400 & $?$ \\
\hline \multirow[t]{5}{*}{ Fisheries (1972) } & Asau village, Ramu River [42] & Gillnet catch (19 Aug 1972): 1 sawfish & 550 & $?$ \\
\hline & Jubin village, Ramu River [42] & Gillnet catch (21-22 Aug 1972): 3 sawfish & 550 and 2200 & $?$ \\
\hline & Akurea village, Ramu River [42] & Gillnet catch (23 Aug 1972): 1 sawfish & 800 & $?$ \\
\hline & Bangapela village, Ramu River [41] & Gillnet catch (28 Aug 1972): 1 sawfish & 1425 & $?$ \\
\hline & $\begin{array}{l}\text { Bulna or Borewa village, } \\
\text { Ramu River [41] }\end{array}$ & Gillnet catch (31 Aug 1972): 9 sawfish & $1200-1400$ & $?$ \\
\hline \multirow[t]{2}{*}{ Anonymous (1973) } & Mouth of Morehead River [20] & $\begin{array}{l}\text { Gillnet catches (12-14 Mar 1973): } \\
1 \text { P. microdon and many P. clavata }\end{array}$ & - & $\begin{array}{l}\text { P. pristis, } \\
\text { P. clavata }\end{array}$ \\
\hline & Mouth of Bensbach River [18] & $\begin{array}{l}\text { Gillnet catches (12-14 Mar 1973): } \\
11 \text { Pristis clavata caught }\end{array}$ & - & P. clavata \\
\hline \multirow[t]{3}{*}{ Filewood (1973) } & Papua New Guinea & Platypristis cuspidatus common & & $\begin{array}{l}\text { Anoxypristis } \\
\text { cuspidata }\end{array}$ \\
\hline & & Pristis zijaron rare & & Pristis zijsron \\
\hline & & Pristis microdon present & & P. pristis \\
\hline Berra et al. (1975) & Laloki River [35] & $\begin{array}{l}\text { Gillnet catches ( } 29 \text { May to } 11 \text { Jun } 1970) \text { : } \\
5 \text { P. microdon caught }\end{array}$ & $830-1635$ & P. pristis \\
\hline Haines (1977) & Purari River and delta [25-28] & P. microdon present & - & $?$ \\
\hline Roberts (1978) & Middle Fly River $[2,4-5,8,11-12]$ & $\begin{array}{l}\text { P. microdon common in Middle Fly (USNM } \\
217001 \text { and 217002); likely reproduces } \\
\text { in Middle Fly due to presence of neonate }\end{array}$ & 809 and 916 & $?$ \\
\hline Haines (1978/1979) & Purari delta [25-28] & See Haines \& Stevens (1983) & - & $?$ \\
\hline \multirow[t]{2}{*}{ Haines (1979) } & Purari River and delta [25-28] & $\begin{array}{l}\text { P. microdon common }\left(5-10 \mathrm{catch}^{-1}\right) \text { in coastal } \\
\text { areas }[28], \text { rarer in upstream waters }[25,26]\end{array}$ & $\begin{array}{l}500-3540 \\
(\mathrm{n}=50)\end{array}$ & $?$ \\
\hline & Kikori River [23, 24] & $\begin{array}{l}P . \text { microdon common }\left(1-4 \mathrm{catch}^{-1}\right) \text { in coastal } \\
\text { areas and side branches of river }\end{array}$ & & $?$ \\
\hline $\begin{array}{l}\text { Haines \& Stevens } \\
\text { (1983) }\end{array}$ & $\begin{array}{l}\text { Purari-Kikori delta area } \\
{[24,27-30]}\end{array}$ & $\begin{array}{l}\text { Survey of fishing villages Feb 1976: grouped } \\
\text { category with sharks }\end{array}$ & - & $?$ \\
\hline \multirow[t]{2}{*}{ Chapau \& Opnai } & Western Gulf of Papua [22] & $\begin{array}{l}\text { Taiwanese drift gillnet surveys (Oct, Dec } 1976 \\
\text { and Jan 1977): Pristiopsis microdon } 2.8 \% \\
\text { of catch by number, } 30 \% \text { by weight; } \\
57 \text { ind. in Dec and } 189 \text { in Jan }\end{array}$ & - & $?$ \\
\hline & & $\begin{array}{l}\text { Commercial data in } 1981 \text { and 1982: P. microdon } \\
5 \% \text { of catch by weight }\end{array}$ & - & $?$ \\
\hline Coates (1983a) & $\begin{array}{l}\text { Sepik River upstream to at least } \\
\text { Ambunti [44] }\end{array}$ & $\begin{array}{l}\text { Not caught but no doubt occurs in river channels } \\
\text { with rostra seen in many villages }\end{array}$ & & P. pristis \\
\hline Coates (1983b) & $\begin{array}{l}\text { Magendo and Imbuando, } \\
\text { Sepik River [46] }\end{array}$ & $\begin{array}{l}\text { Villagers sometimes catch in bottom gillnets } \\
\text { in shallow waters }\end{array}$ & - & $?$ \\
\hline Frielink (1983) & Delta of the Gulf Province [23-30] & One of top 11 species groups in fisheries catches & - & $?$ \\
\hline
\end{tabular}


Table 1 (continued)

\begin{tabular}{|c|c|c|c|c|}
\hline Source & $\begin{array}{l}\text { Location } \\
\text { [map reference] }\end{array}$ & Notes & $\begin{array}{l}\text { Size } \\
(\mathrm{TL} ; \mathrm{mm})\end{array}$ & Species \\
\hline Coates (1987) & Sepik River [44-46] & $\begin{array}{l}\text { P. microdon is rare and likely breeds } \\
\text { in the upper river }\end{array}$ & - & P. pristis \\
\hline Osborne (1987) & Papua New Guinea & P. microdon widespread in all rivers & - & P. pristis \\
\hline $\begin{array}{l}\text { Allen \& Coates } \\
(1990)\end{array}$ & Sepik River [44-46] & $\begin{array}{l}\text { Not caught but local fishers possessed } \\
\text { dried rostra }\end{array}$ & - & P. pristis \\
\hline $\begin{array}{l}\text { Smith \& Hortle } \\
\text { (1991) }\end{array}$ & Fly River & P. microdon recorded in Fly & - & P. pristis \\
\hline $\begin{array}{l}\text { Taniuchi et al. } \\
\text { (1991), Taniuchi \& }\end{array}$ & $\begin{array}{l}\text { Magendo 1-3 and Angoram, } \\
\text { Sepik River [46] }\end{array}$ & $\begin{array}{l}\text { Gillnet catches (3-8 Sep 1989) P. microdon: } \\
8 \text { males and } 4 \text { females caught (salinity 0-2) }\end{array}$ & $\begin{array}{l}778-870(\mathrm{M}) \\
794-869(\mathrm{~F})\end{array}$ & P. pristis \\
\hline Shimizu (1991), & Jagita, Bobowa and Miwa & Gillnet catches (17-23 Sept 1989) P. microdon: 92 & $925-2473(\mathrm{M})$ & \\
\hline $\begin{array}{l}\text { Mizue \& Hara (1991), } \\
\text { Ishihara et al. (1991), } \\
\text { Watabe (1991), }\end{array}$ & in Lake Murray [8-9] & 12 males and 11 females caught (salinity $0-1$ ) 9 & $970-1279(\mathrm{~F})$ & P. pristis \\
\hline Tanaka (1991) & Oriomo River Estuary [21] & $\begin{array}{ll}\text { Gillnet catches (24-25 Sep 1989): } & 3611 \\
1 \text { male } P \text {. microdon and } 1 \text { male } A . & 1182 \\
\text { cuspidata caught (salinity 20-25) } & \end{array}$ & $\begin{array}{l}11 \text { (P. microdon) } \\
82(\text { A. cuspidata })\end{array}$ & $\begin{array}{l}\text { P. pristis, } \\
\text { A. cuspidata }\end{array}$ \\
\hline Allen et al. (1992) & Bunapas, Ramu River [43] & Not caught but rostra recorded (e.g. CAS 63666) & - & P. pristis \\
\hline Coates (1993) & Sepik and Ramu Rivers [40-46] & P. microdon present in both rivers & - & P. pristis \\
\hline $\begin{array}{l}\text { Smith \& Bakowa } \\
\text { (1994) }\end{array}$ & $\begin{array}{l}\text { Floodplains of Upper } \\
\text { and Middle Fly River [1-7] }\end{array}$ & P. microdon caught & - & P. pristis \\
\hline \multirow[t]{2}{*}{ Burton (1995) } & Mipan village, Middle Fly [3] & $\begin{array}{l}\text { P. microdon previously caught but listed by } \\
\text { villagers as absent from area due to overfishing }\end{array}$ & - & P. pristis \\
\hline & Wanga-Wanga, Middle Fly [7] & $\begin{array}{l}\text { One sawfish caught at Obo in } 1994 \text {, } \\
\text { none seen recently }\end{array}$ & - & $?$ \\
\hline Hyslop (1996) & Lower Angabanga River [32-33] & $\begin{array}{l}\text { P. microdon recorded from seine net catches } \\
\text { in lower, non-tidal reaches }\end{array}$ & - & $?$ \\
\hline $\begin{array}{l}\text { Powell \& Powell } \\
\text { (1999) }\end{array}$ & Mariropa River, Bougainville [58] & $\begin{array}{l}\text { P. microdon recorded at } 2 \text { lower reach locations } \\
\text { between } 1975 \text { and } 1988\end{array}$ & $1000-1200$ & P. pristis \\
\hline Swales et al. (1999) & Fly and Strickland River $[5-7,10]$ & $\begin{array}{l}P . \text { microdon recorded in gillnet catches and } \\
\text { in one rotenone site }\end{array}$ & - & P. pristis \\
\hline Jenkins (2000) & Lake Lalili, West New Britain [50] & $\begin{array}{l}\text { Potentially unharvested populations } \\
\text { of } P \text {. microdon found }\end{array}$ & - & P. pristis \\
\hline Swales et al. (2000) & Fly River [1, 5, 7, 14-16] & P. microdon caught in gillnets & - & P. pristis \\
\hline Hitchcock (2002) & Middle Bensbach River [19] & One $P$. microdon caught in gillnet & - & P. pristis \\
\hline Swales (2002) & Upper and Middle Fly River & $\begin{array}{l}\text { P. microdon becoming less frequent in catches } \\
\text { in main channel sites }\end{array}$ & - & P. pristis \\
\hline Hitchcock (2004) & Middle Bensbach River [19] & $\begin{array}{l}\text { P. microdon caught by local fishers (see Hitchcock } \\
\text { 2002) and fins traded with Indonesian merchants } \\
\text { at Sota }\end{array}$ & $\mathrm{k}$ & P. pristis \\
\hline Storey et al. (2009) & Middle Fly River & $\begin{array}{l}\text { Once common in Middle Fly but not seen upstream } \\
\text { of Everill Junction [7] for past } 15 \text { yr; still common } \\
\text { downstream and in Strickland River }\end{array}$ & $\mathrm{am}$ & P. pristis \\
\hline Loop (2015) & Wakunai, Bougainville [56] & $\begin{array}{l}\text { A large sawfish caught in net by fishers } \\
\text { in a canoe in June } 2015\end{array}$ & $>4000$ & P. pristis \\
\hline \multicolumn{5}{|c|}{ Personal communications } \\
\hline $\begin{array}{l}\text { Garrick Hitchcock, } \\
\text { Arafura Consulting, }\end{array}$ & $\begin{array}{l}\text { Balamuk village, Bensbach River } \\
\text { [19] }\end{array}$ & Two sawfish caught in gillnet (16 Oct 1997) & - & P. pristis \\
\hline Aug 2016 & $\begin{array}{l}\text { Wando village, Bensbach River } \\
\text { [19] }\end{array}$ & $\begin{array}{l}\text { Sawfish rostra kept as decorative items } \\
\text { in many houses in area }\end{array}$ & - & P. pristis \\
\hline $\begin{array}{l}\text { Garry Barmby, } \\
\text { Angling Adventures, } \\
\text { Aug } 2016\end{array}$ & $\begin{array}{l}\text { Lake Murray [8-9], Bensbach } \\
\text { s, } \\
\text { [20] Rivers }\end{array}$ & $\begin{array}{l}\text { No sawfish observed in at least the last } 4 \mathrm{yr} \\
\text { [18-19] and Morehead }\end{array}$ & - & - \\
\hline $\begin{array}{l}\text { Kevin Atana, NFA } \\
\text { provincial officer, } \\
\text { Buka, Oct } 2016\end{array}$ & Nissan Atoll [55] & $\begin{array}{l}\text { Large sawfish observed on atoll whilst free } \\
\text { diving }(\sim 10 \text { yr prior })\end{array}$ & - & $?$ \\
\hline $\begin{array}{l}\text { Riccard Reimann, } \\
\text { Baia Sportfishing, } \\
\text { Jul } 2016\end{array}$ & $\begin{array}{l}\text { Mouths of Via, Pandi and Toriu } \\
\text { Rivers, West New Britain [51-52] }\end{array}$ & $\begin{array}{l}\text { Observed near mouths of rivers between May } \\
\text { and Nov leading up to New Moon and just } \\
\text { before whitebait enter rivers }\end{array}$ & $\begin{array}{l}\sim 3000-3658 \\
(10-12 \mathrm{ft})\end{array}$ & $?$ \\
\hline $\begin{array}{l}\text { Ray Moore (retired), } \\
\text { Jul } 2016\end{array}$ & $\begin{array}{l}\text { Daru region [21] and surrounds } \\
\text { Lake Murray [8-9] }\end{array}$ & $\begin{array}{l}\text { In 1970-1980: } P \text {. microdon most common, } \\
\text { One P. microdon caught in } 1972 \\
\text { Bensbach River to Gulf; } P \text {. zijsron rare, only } \\
\text { in coastal waters; Anoxypristis cuspidata only } \\
\text { in coastal waters }\end{array}$ & $\begin{array}{c}- \\
\sim 5000 \\
(16 \mathrm{ft} 5 \mathrm{in})\end{array}$ & $\begin{array}{l}\text { P. pristis, } \\
\text { P. pristis } \\
\text { P. zijsron, } \\
\text { A. cuspidata }\end{array}$ \\
\hline
\end{tabular}


were lost or destroyed between 1998 and 2002. The remains of the collection is now housed at the University of Papua New Guinea in Waigani, Port Moresby. A large number of sawfish specimens were among those lost or destroyed (see footnote in Table 2).

\section{Recent records}

Records of sawfish from fisheries catches were collated from data obtained during an intensive project on sharks and rays in PNG which commenced in 2014. The PNG National Fisheries Authority (NFA) deployed observers on 7 separate prawn trawl trips in the Gulf of Papua between June 2014 and September 2015. Observers recorded all sharks and rays caught during trawl activities and obtained basic data such as species, size, sex and, where possible, maturity stage. Additionally, coastal fisheries catches were examined during a series of artisanal fisheries survey trips, with sawfish recorded during surveys of Daru and Katatai (October 2014; map reference 21 in Fig. 1), Bougainville (October 2015) and Milne Bay (March 2016).

Dried fins were examined at the local fish buyers during artisanal surveys (see also White et al. 2015)

Table 2. Sawfish from Papua New Guinea in various museum collections around the world. Museum abbreviations follow the international standard codes (see Fricke \& Eschmeyer 2016). Numbers in square brackets are references to locations in Fig. 1. Sizes are given in total length (TL) or standard length (SL); TRL: total rostral length; ?: unknown whether this was a whole specimen or only rostrum; -: no data available

\begin{tabular}{|c|c|c|c|c|c|c|c|}
\hline $\begin{array}{l}\text { Registration } \\
\text { or field no. }\end{array}$ & $\mathrm{n}$ & Part & Date & Locality [map reference] & $\begin{array}{l}\text { TRL } \\
(\mathrm{mm})\end{array}$ & $\begin{array}{l}\text { Size } \\
(\mathrm{mm})\end{array}$ & Sex \\
\hline \multicolumn{8}{|l|}{ Anoxypristis cuspidata } \\
\hline FUMT-P10855 & 1 & Whole & 24 Sep 1989 & Oriomo River Estuary [21] & - & TL: 1182 & $\mathrm{M}$ \\
\hline KFRS E028 & 1 & $?$ & Oct 1963 & Hall Sound [34] & - & - & - \\
\hline KFRS E142 ${ }^{\mathrm{a}}$ & 1 & $?$ & Jun 1964 & Yule Island [34] & - & - & - \\
\hline KFRS E166 ${ }^{\mathrm{a}}$ & 3 & $?$ & Aug 1965 & S of Ramu River mouth [43] & - & - & - \\
\hline KFRS E191 ${ }^{\mathrm{a}}$ & 5 & $?$ & Dec 1965 & Darapap area [47] & - & - & - \\
\hline KFRS E238 & 1 & $?$ & & $\mathrm{~N}$ of Yule Island [34] & - & - & - \\
\hline KFRS E375 & 1 & $?$ & 29 Mar 1969 & Yule Island [34] & - & - & - \\
\hline KFRS E394 ${ }^{\mathrm{a}}$ & 1 & $?$ & 20 Dec 1969 & Panaroa River [28] & - & - & - \\
\hline KFRS E $404^{\mathrm{a}}$ & 1 & $?$ & 7 Apr 1970 & Bootless Bay [37] & - & - & - \\
\hline KFRS E $427^{a}$ & 2 & $?$ & & Daru [21] & - & - & - \\
\hline KFRS unreg & 1 & Whole & - & Nigoherm Islands [48] & - & TL: 570 & F \\
\hline $\begin{array}{l}\text { 10/2000 } \\
\text { (in Faria et al. 2013) }\end{array}$ & 1 & Rostrum & Oct 2000 or earlier & Gulf of Papua & - & - & - \\
\hline \multicolumn{8}{|l|}{ Pristis clavata } \\
\hline KFRS E $205^{\mathrm{a}}$ & 1 & $?$ & Feb 1966 & Alele River mouth [30] & - & - & $\mathrm{F}$ \\
\hline KFRS E $221^{\mathrm{a}}$ & 1 & ? & 14 Feb 1966 & Alele River [30] & - & - & - \\
\hline KFRS E $224^{\mathrm{a}}$ & 3 & $?$ & 13 Mar 1966 & Port Romilly [27] & - & - & $2 \mathrm{~F}, 1 \mathrm{M}$ \\
\hline KFRS E236 ${ }^{a}$ & 1 & $?$ & 12-13 Mar 1966 & Port Romilly [27] & - & - & - \\
\hline KFRS E237 ${ }^{a}$ & 1 & $?$ & 22 Mar 1966 & $\mathrm{~N}$ of Yule Island [34] & - & - & - \\
\hline KFRS E372 & 1 & $?$ & Mar 1966 & Alele River [30] & - & - & - \\
\hline KFRS E428 & 1 & Rostrum & - & Daru [21] & 178 & TL: $\sim 890$ & - \\
\hline \multicolumn{8}{|l|}{ Pristis pristis } \\
\hline AMS I $30207-001^{\mathrm{a}}$ & 1 & $?$ & Aug 1988 & Magendo, Sepik River [46] & - & TL: 784 & - \\
\hline AMS IB. 2854 & 1 & Rostrum & 6 Aug 1952 & Laloki River, near Bomana [35] & - & SL: 735 & - \\
\hline CAS 63666 & 2 & Rostra & 18 Oct 1987 & Bunapas, Ramu River [43] & - & - & - \\
\hline CAS SU 41013 & 1 & Rostrum & 23 May 1929 & Korogu village, Sepik River [45] & - & - & - \\
\hline CAS SU 41014 & 1 & Rostrum & 23 May 1929 & Korogu village, Sepik River [45] & - & - & - \\
\hline FUMT-P10851 & 1 & Whole & 3 Sep 1989 & Magendo 3, Sepik River [46] & - & TL: 801 & $\mathrm{M}$ \\
\hline FUMT-P10854 & 1 & Whole & 17 Sep 1989 & Miwa, Lake Murray [9] & - & TL: 970 & $\mathrm{~F}$ \\
\hline KFRS E024 & 1 & Rostrum & Oct 1963 & Hall Sound [34] & 1270 & TL: $\sim 5292$ & - \\
\hline KFRS E025 a & 1 & ? & Oct 1963 & Hall Sound [34] & - & - & - \\
\hline KFRS E026A & 1 & Rostrum & 27 Jun 1964 & Vanapa River [35] & 194 & TL: $~ 808$ & - \\
\hline KFRS E026B & 1 & Rostrum & 27 Jun 1964 & Vanapa River [35] & 203 & TL: $~ 846$ & - \\
\hline KFRS E027A & 1 & Rostrum & Aug 1964 & Laloki River [35] & 225 & TL: $~ 938$ & - \\
\hline KFRS E027B & 1 & $?$ & Aug 1964 & Laloki River [35] & - & - & - \\
\hline KFRS E032A & 1 & Rostrum & Jun 1964 & Yule Island [34] & 242 & TL: 1008 & - \\
\hline
\end{tabular}


Table 2 (continued)

\begin{tabular}{|c|c|c|c|c|c|c|c|}
\hline $\begin{array}{l}\text { Registration } \\
\text { or field no. }\end{array}$ & No. & Part & Date & Locality [map reference] & $\begin{array}{l}\text { TRL } \\
(\mathrm{mm})\end{array}$ & $\begin{array}{l}\text { Size } \\
(\mathrm{mm})\end{array}$ & Sex \\
\hline KFRS E032B & 1 & Rostrum & Jun 1964 & Yule Island [34] & 263 & TL: 1096 & - \\
\hline KFRS E092 ${ }^{\mathrm{a}}$ & 4 & $?$ & Dec 1962 & Orangerie Bay [39] & - & - & - \\
\hline KFRS E256 ${ }^{\mathrm{a}}$ & 1 & ? & - & Warangoi River [54] & - & - & M \\
\hline KFRS E278 & 1 & Rostrum & - & $?$ & 242 & TL: 1008 & - \\
\hline KFRS E380 & 1 & Embryo & Nov 1969 & Kairuku [34] & - & - & - \\
\hline KFRS E418 & 1 & $?$ & 19 Dec 1970 & Aiome, Ramu River [40] & - & - & - \\
\hline KFRS E429A & 1 & Rostrum & - & Oriomo River [21] & 292 & TL: 1217 & - \\
\hline KFRS E429B & 1 & Rostrum & - & Oriomo River [21] & 237 & TL: 988 & - \\
\hline KFRS unreg PNG232 & 1 & Whole & 21 Oct 2007 & Sapuka, Fly River [13] & - & TL: 870 & M \\
\hline QM I 3686 & 1 & Rostrum & - & $?$ & - & - & - \\
\hline QM I 3687 & 1 & Rostrum & - & ? & - & - & - \\
\hline USNM 217001 & 1 & Whole & 27 Nov 1975 & $\begin{array}{l}\text { Wam River, swampy lagoons } \\
\text { of the Middle Fly [6] }\end{array}$ & - & TL: 809 & F \\
\hline USNM 217002 & 1 & Whole & 6 Dec 1975 & $\begin{array}{l}\text { Side channel of Strickland } 4 \mathrm{~km} \\
\text { downstream from Massy Baker } \\
\text { Junction [11] }\end{array}$ & rs & TL: 916 & $\mathrm{M}$ \\
\hline ZMB 14507 & $1 \mathrm{Rc}$ & strum + parts & s 1896 or 1899 & Ramu River [40-43] & 225 & TL: 938 & - \\
\hline ZMB 32538 & 1 & Rostrum & Early 1900s & Bismarck Archipelago & 1030 & TL: $\sim 4292$ & - \\
\hline ZMB 33545 & 1 & Whole & Aug 1913 & $\begin{array}{l}\text { 'Tschessbandai', west of } \\
\text { Korogu, Middle Sepik [45] }\end{array}$ & - & TL: $\sim 700$ & $\mathrm{~F}$ \\
\hline ZMB 33553 & 1 & Rostrum & - & New Guinea & 273 & TL: 1138 & - \\
\hline $\begin{array}{l}\text { 3/1998 (in Faria et al. } \\
\text { 2013) }\end{array}$ & 1 & Rostrum $\mathrm{I}$ & Mar 1998 or earlier & Gulf of Papua & - & - & - \\
\hline $\begin{array}{l}\text { 12/1999 (in Faria et al. } \\
\text { 2013) }\end{array}$ & 3 & Rostra & Dec 1999 or earlier & Sepik River [44-46] & & & \\
\hline $\begin{array}{l}\text { Unregistered (in } \\
\text { Seeadler Hotel) }\end{array}$ & 1 & Rostrum & - & $\begin{array}{l}\text { Seeadler Harbour, Manus [49] } \\
\text { (genetic sample \# 180758) }\end{array}$ & 790 & TL: 3292 & - \\
\hline $\begin{array}{l}\text { Unregistered (in } \\
\text { Rabaul Hotel) }\end{array}$ & 1 & Rostrum & - & Rabaul Hotel, Rabaul [53] & $\sim 1200$ & TL: 5000 & - \\
\hline \multicolumn{8}{|l|}{ Pristis zijsron } \\
\hline CAS SU 40592 & 1 & Rostrum & May 1929 & Sepik River [44-46] & 409 & TL: 1515 & - \\
\hline KFRS E049a & 1 & $?$ & May 1965 & Yule Island [34] & & & \\
\hline KFRS E378 & 1 & Rostrum & May-Jul 1968 & Balimo area [17] & 285 & TL: 1056 & - \\
\hline KFRS E $411^{\mathrm{a}}$ & 1 & $?$ & 8 May 1970 & Bootless Bay [37] & & & \\
\hline KFRS unreg (200781) & 1 & Rostrum & - & $\begin{array}{l}\text { Probably either KFRS E049 } \\
\text { or E411 above }\end{array}$ & 880 & TL: 3259 & - \\
\hline
\end{tabular}

and from the larger fish buyers in Port Moresby. Key standard morphological measurements of first dorsal (length, height, anterior margin) and caudal (dorsal margin) fins were taken. Tissue samples were taken from all dried fins and DNA barcoding was employed to determine the species involved. DNA barcoding using the COI gene follows the methodology provided in White et al. (2015). Since sawfish dorsal fins are similar in size and shape, any dorsal fins that were found to be sawfish needed to be matched into pairs and with a caudal fin (if present) to avoid duplication of numbers in the dried fin batches. For sawfish fins, morphometric measurements were used to estimate total length of the individual by using data obtained from museum specimens in the CSIRO Australian National Fish Collection and measurements in Wallace (1967) and Faria et al. (2013). The proportions used to calculate these lengths are provided in Table 3. For dorsal fins, length was considered the most accurate measurement, with dorsal fin height in particular producing much larger estimated sizes, especially for A. cuspidata. When only dried sawfish rostra were observed, the total rostral length (TRL) of each rostrum was taken and the total length (TL) estimated using the TRL/TL morphometric data presented in Whitty et al. (2014).

All recent sawfish records are summarised in Table 4 . 


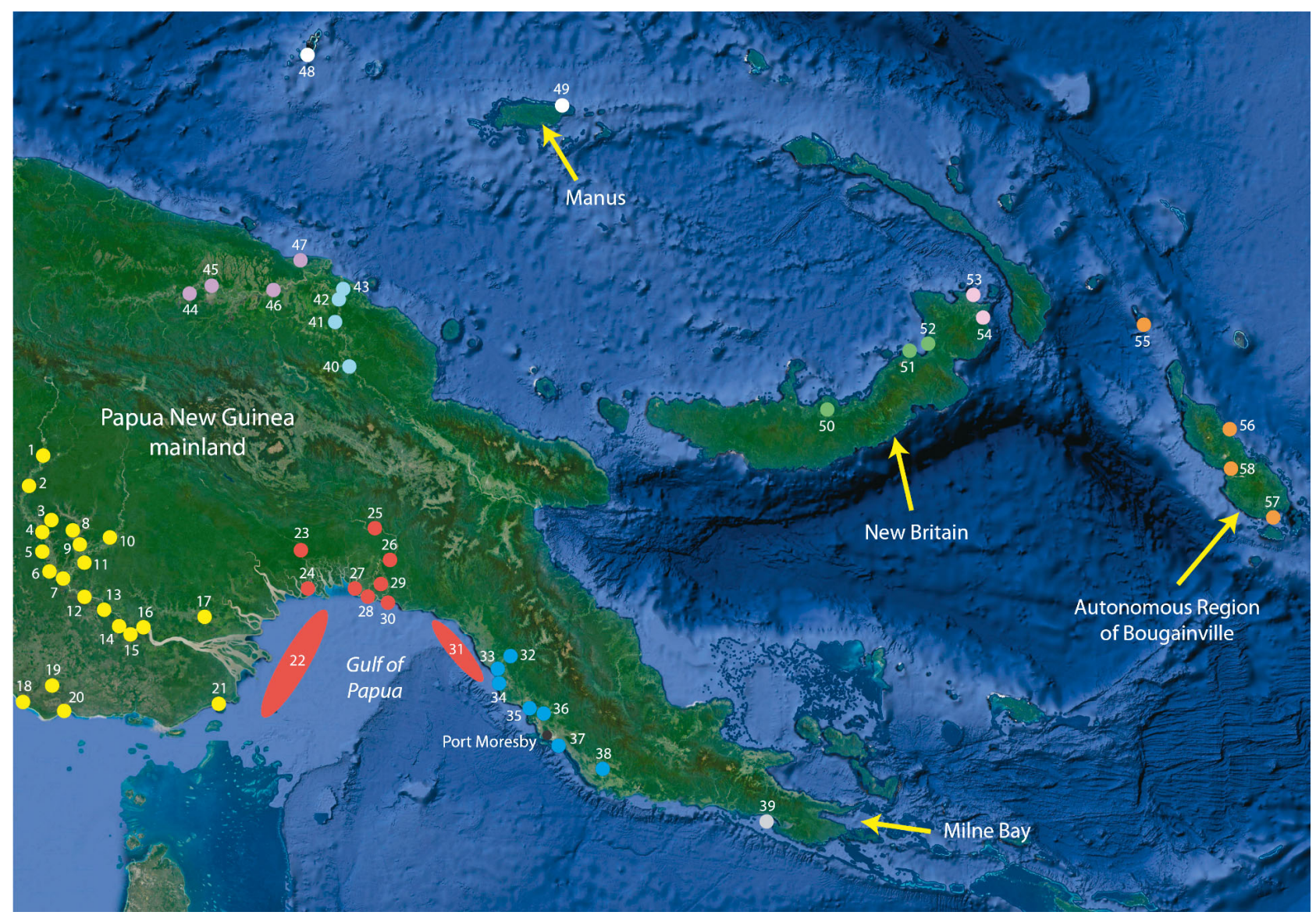

Fig. 1. Locations where sawfish have been recorded in Papua New Guinea. Each numbered reference point corresponds to the map reference in Tables 1, 2 \& 4. Provinces (colour of points): Western (yellow; 1-21), Gulf (red; 22-31), Central (blue; 32-38), Milne Bay (grey; 39), Madang (cyan; 40-43), East Sepik (purple; 44-47), Manus (white; 48-49), West New Britain (green; 50-52), East New Britain (pink; 53-54) and the Autonomous Region of Bougainville (orange; 55-58). Base image @ NASA, TerraMetrics, Google Earth

\section{RESULTS}

\section{Historical records}

Table 1 summarises all literature records sourced during this study, including both published and unpublished papers, reports and trip summaries. The first published records of sawfish in PNG were from
Herre (1936), who recorded Pristis perotteti (= P. pristis) from the Sepik River in May 1929 during the Crane Pacific Expedition. Two P. pristis and 1 P. zijsron rostra were collected by Herre and were deposited in the Californian Academy of Sciences ichthyological collection (see Table 2). Interestingly, only the $2 P$. pristis jaws were mentioned in Herre (1936) as having been collected from Koragu (= Ko-

Table 3. Number of sawfish specimens used (n) and mean $( \pm \mathrm{SE})$ proportions of first dorsal fin length (D1L), first dorsal fin height (D1H), first dorsal fin anterior margin (D1A) and dorsal caudal margin (DCM) to total length (TL) for the 4 sawfish species

\begin{tabular}{|c|c|c|c|c|c|c|c|c|}
\hline & \multicolumn{2}{|c|}{$-\mathrm{D} 1 \mathrm{~L} / \mathrm{TL}-$} & \multicolumn{2}{|c|}{$-\mathrm{D} 1 \mathrm{H} / \mathrm{TL}-$} & \multicolumn{2}{|c|}{$-\mathrm{D} 1 \mathrm{~A} / \mathrm{TL}-$} & \multicolumn{2}{|c|}{$-\mathrm{DCM} / \mathrm{TL}-$} \\
\hline & $\mathrm{n}$ & Mean $( \pm \mathrm{SE})$ & $\mathrm{n}$ & Mean $( \pm \mathrm{SE})$ & $\mathrm{n}$ & Mean $( \pm \mathrm{SE})$ & $\mathrm{n}$ & Mean $( \pm \mathrm{SE})$ \\
\hline Anoxypristis cuspidata & 1 & 0.09 & 1 & 0.08 & 1 & 0.10 & 1 & 0.13 \\
\hline Pristis clavata & 4 & $0.10( \pm 0.000)$ & 5 & $0.06( \pm 0.002)$ & 5 & $0.09( \pm 0.001)$ & 5 & $0.14( \pm 0.001)$ \\
\hline Pristis pristis & 3 & $0.10( \pm 0.002)$ & 13 & $0.07( \pm 0.001)$ & 9 & $0.10( \pm 0.003)$ & 10 & $0.16( \pm 0.003)$ \\
\hline Pristis zijsron & 1 & 0.08 & - & - & 1 & 0.07 & 1 & 0.13 \\
\hline
\end{tabular}




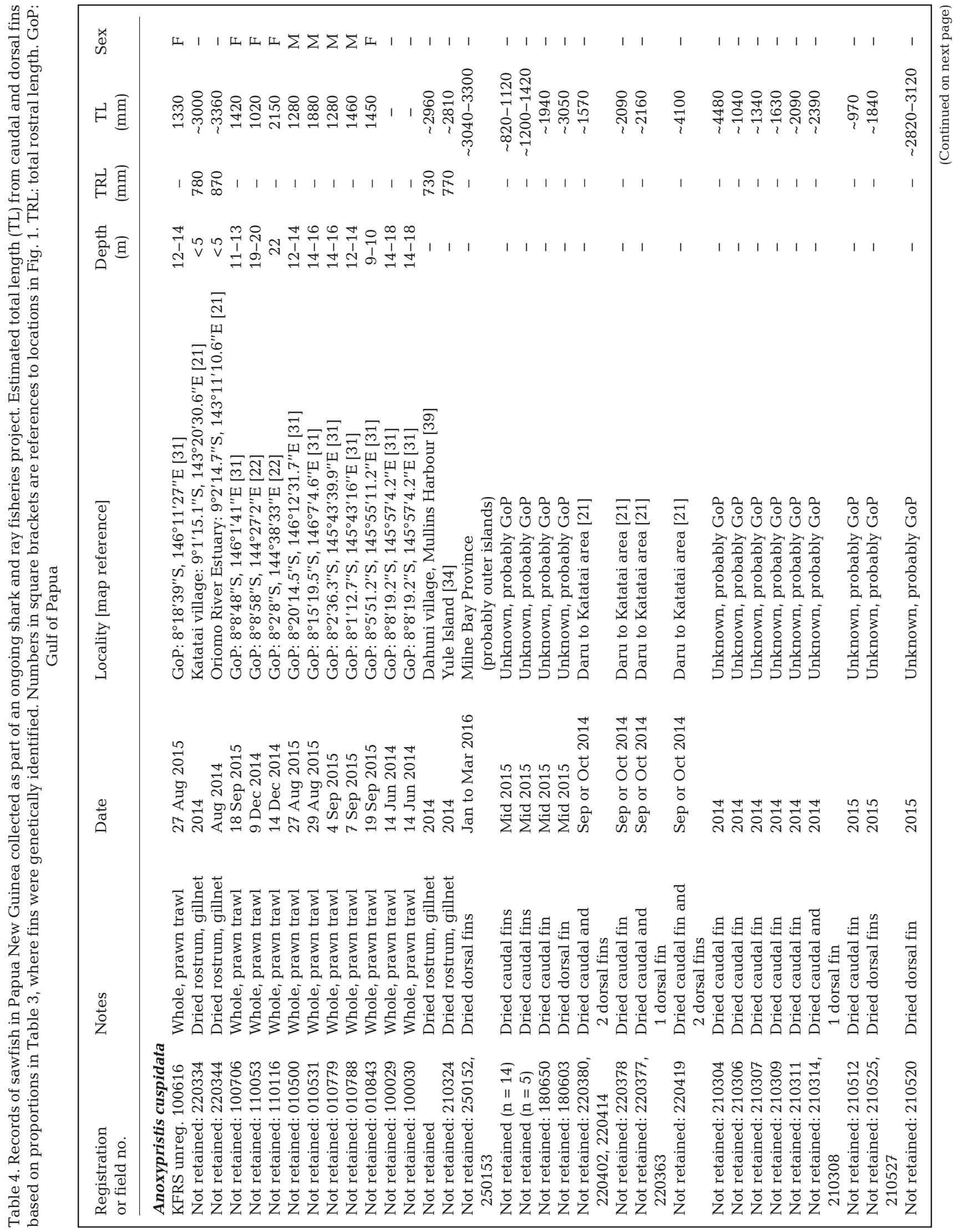




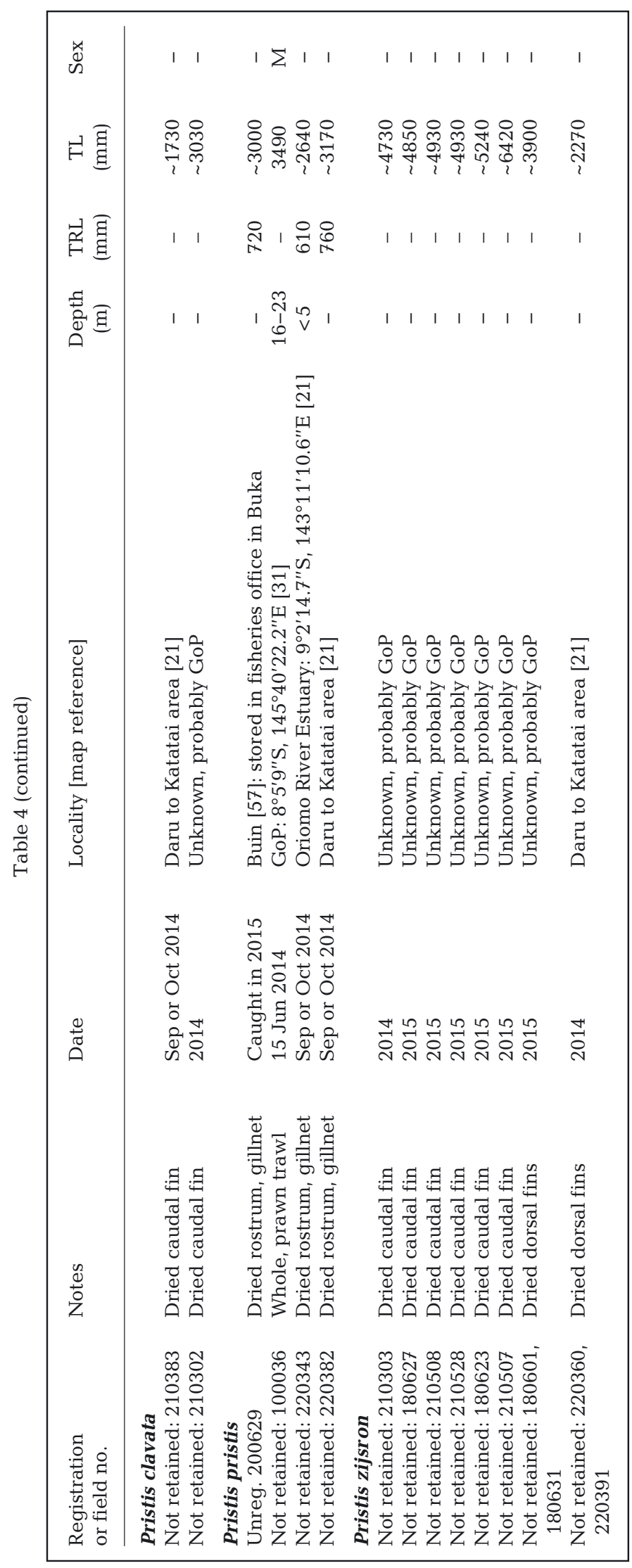

rogu), $346 \mathrm{~km}$ from the sea. Given that P. zijsron is normally found in coastal waters and not far into rivers (Stevens et al. 2005), the P. zijsron rostrum (CAS SU 40592) was possibly collected or acquired near the mouth of the Sepik River. Alternatively, it could have been collected from near Madang and Sek, the only other 2 PNG localities sampled during this expedition; however, Sepik River is hand written on the rostrum itself.

The first detailed list of the fishes of New Guinea (Munro 1958) included Pristis microdon based on the Korogu record of Herre (1936). Munro (1964) listed 2 species of sawfish, Pristiopsis leichhardti and Pristiopsis microdon, which occurred in southern and northern New Guinea, respectively. The comprehensive guide to fishes in Munro (1967) included treatments for these 2 species, both of which are now synonomised with Pristis pristis. The treatments for both species refer to the anteriorly placed first dorsal fin (relative to the pelvic fins) which confirms they both refer to $P$. pristis. The separation of the 2 'species' was originally based on the free rear tip of the second dorsal fin reaching the caudal fin in $P$. leichhardti or well separated in P. microdon (see Munro 1967). It is possible this observation was an artefact of comparing different size classes (with damaged free rear tips in some specimens) or intraspecific variation.

Many of the literature sources examined include records of $P$. microdon in the catches (e.g. Hinton 1967, Glucksman 1969, Haines 1979, Chapau \& Opnai 1983), but the identity of the species cannot be confirmed in most cases. In other sources, the catches included only reference to sawfish without specific species being mentioned (e.g. Rapson \& McIntosh 1971, Anonymous 1972, Burton 1995).

Filewood (1973) produced the first detailed key to the elasmobranchs of PNG, but unfortunately this was never published and thus only used by those who had access to the few copies available. The key included the first mention of the species Platypristis cuspidatus $(=$ A. cuspidata $)$ and Pristis zijaron $(=P$. zijsron $)$, as well as $P$. microdon ( $=P$. pristis) but did not include $P$. clavata. Confidence can be placed on the identity of P. zijsron in Filewood (1973) as the key difference provided is the unequal spacing of the rostral teeth (i.e. wider spacing at the base and closer together at the tip), which is the key character for this species. The records of $P$. cuspidatus and $P$. microdon can also be confirmed from the information provided, i.e. origin of first dorsal opposite or behind pelvic origin versus well before. However, there is an error in one character difference in the key, with the lack of a distinct ventral caudal lobe attributed to $P$. cuspidatus. 
Depth of Agriculture, Stock and Fisheries (1973) was the first survey report to record more than one species of sawfish, with both $P$. microdon and $P$. clavata caught during gillnet surveys at the mouth of the Morehead River in Western Province. In this survey report, only a single $P$. microdon was recorded, but $P$. clavata was abundant at this location and at the mouth of the Bensbach River. Although P. clavata was reported to be abundant, it is not possible to confirm the identifications of these records. As these records could also refer to A. cuspidata or P. zijsron, this identification must be treated with caution.

It is important to note that in a number of studies, sawfish were recorded as being abundant in the catches or common according to villagers in the areas visited. For example, Haines (1979) found that sawfish were common in the Purari-Kikori delta region with between 5 and 10 ind. per catch in coastal areas of the Purari and 1 to 4 ind. per catch in coastal areas and side branches of the Kikori. Likewise, Roberts (1978) reported that $P$. microdon ( $=$ P. pristis) was common in the Middle Fly River.

\section{Fisheries catches}

The largest catch records of sawfish in the available literature are from the trial fishery surveys, which used Taiwanese drift gillnets in the Gulf of Papua in October and December 1976 and January 1977 (Chapau \& Opnai 1983). During these trial surveys, Pristiopsis microdon (= P. pristis) accounted for $30.1 \%$ by weight and $2.7 \%$ by number of the total catch. In December 1976, 57 ind. were recorded with a combined weight of $4500 \mathrm{~kg}$, and in January 1977 , 189 ind. were recorded with a combined weight of $12382 \mathrm{~kg}$. These equate to an average weight per individual of $69 \mathrm{~kg}$. The majority of the sawfish were caught in the shallower sets ( 7 to $15 \mathrm{~m}$ depth) near the mouth of the Fly River. The gillnets used in these surveys were $3440 \mathrm{~m}$ long and $14 \mathrm{~m}$ deep with $15.2 \mathrm{~cm}$ mesh (Chapau \& Opnai 1983), thus touching the bottom at these depths. The identity of the species of sawfish involved is not possible to determine and likely consisted of multiple species in the total catch.

Subsequent commercial fishing commenced in mid-1980 with 5 Taiwanese drift gillnet fishing vessels operating through 1981, dropping to 2 vessels in 1982. The nets used by the commercial vessels were $9000 \mathrm{~m}$ long, $12 \mathrm{~m}$ deep with $17.8 \mathrm{~cm}$ mesh and were suspended 5 to $6 \mathrm{~m}$ below the surface (Chapau \& Opnai 1983). The 1981 and 1982 commercial data showed total catches of 810 and $405 \mathrm{t}$, respectively, with Pristiopsis spp. comprising 5\% of the catch by weight. This corresponds to about $60.7 \mathrm{t}$ of sawfish caught during this period, which equates to 880 ind. based on the average weight of $69 \mathrm{~kg}$ from the $1976 / 1977$ survey data. No other data is available after this period, but drift gillnetting came under increasing scrutiny in the South Pacific in 1989 (Stewart 1990) and ceased in 1993 (Anas et al. 2000).

Sawfish are currently recorded in the bycatch of the prawn trawlers operating in the Gulf of Papua (see e.g. Table 4). Surveys to assess the viability of establishing prawn trawling in PNG commenced in the mid-1950s (Rapson 1955) and surveys in the mid1960s showed there were commercial quantities of prawns in the Gulf of Papua. Rapson \& McIntosh (1971) reported sawfish present in prawn trawls between Iokea and Orokolo Bay during surveys conducted in February 1963. The commercial Gulf of Papua fishery commenced in 1969 (Evans et al. 1995), and from 1990 to 2011 the number of vessels operating in this fishery ranged from 1 to 18 (mean: 9.8) (Liviko 2012). No previous detailed surveys have been undertaken on the prawn trawl bycatch, but sawfish are likely to be regularly caught in this fishery. In the current study, observer data was collected from 7 prawn trawl fishing trips in the Gulf of Papua between June 2014 and September 2015, representing 403 trawl shots and $1273 \mathrm{~h}$ of trawling. Observers recorded 1 P. pristis of $3490 \mathrm{~mm}$ TL and 11 A. cuspidata ranging from 1020 to $2150 \mathrm{~mm}$ TL (Table 4).

Coastal artisanal fisheries also catch sawfish. In the Middle Bensbach River, sawfish are caught by the Wartha people. The flesh is eaten locally and fins are sold to Indonesian merchants at Sota in West Papua (Hitchcock 2002). Customary cross-border trade is allowed under a treaty between PNG and Indonesia as long as traded goods are not prohibited in either country (Hitchcock 2002). However, according to Government Regulation of the Republic of Indonesia (Number 7) 'Concerning the Conservation of Plant and Animal Species' (www.profauna.net/id/regulasi/ pp-7-1999-tentang-pengawetan-jenis-tumbuhan-dansatwa), all species of the genus Pristis have been protected in Indonesia since 1999. Sawfish have also been reported to have been caught by villagers in the Sepik River (e.g. Coates 1983b), Ramu River (e.g. Allen \& Coates 1990), the Purari-Kikori delta (e.g. Haines \& Stevens 1983) and Bougainville (Loop 2015). During surveys of fishing villages in Daru and Katatai (Western Province) conducted in late 2014, all 4 species of sawfish were observed from gillnet catches (see Table 4). Examination of dried fins from 
fish buyers in Port Moresby found that sawfish fins were commonly present (see Table 4; based on genetic identifications), but catch details were not available and thus the records could have been from either trawl or coastal artisanal fisheries. Most recently, dorsal fins from a single $A$. cuspidata of $\sim 3 \mathrm{~m}$ TL were recorded from a batch of dried fins examined in Alotau, Milne Bay Province (Table 4). These fins come into Alotau from across the Milne Bay Province so no precise location data could be obtained.

In total, $56 A$. cuspidata were recorded in the current study, ranging in length from $\sim 970$ to $\sim 4480 \mathrm{~mm}$ TL (Table 4). Two P. clavata were recorded with estimated lengths of $\sim 1730$ and $\sim 3030 \mathrm{~mm}$ TL. Four $P$. pristis were recorded with lengths between $\sim 2640$ and $3490 \mathrm{~mm}$ TL and $10 \mathrm{P}$. zijsron were recorded with estimated lengths between $\sim 2270$ and $\sim 6420 \mathrm{~mm}$ TL (Table 4). The largest individuals recorded for $A$. cuspidata and $P$. zijsron were based on dried fins, and the proportions used to estimate their total lengths (Table 3) were based on a single juvenile individual for each species. Thus, ontogenetic differences have not been taken into account and the estimates could be over- or underestimates.

\section{Sawfish in collections}

Specimens of sawfish collected from PNG deposited in the various biological collections around the world are compiled in Table 2. The oldest collected sawfish specimen from PNG is ZMB 14507; this record consists of the rostrum and cranium (jaw attached), stomach, and gills and scapulocoracoid of a $\sim 938 \mathrm{~mm}$ TL $P$. pristis. The collector was Dr. Carl Adolf Georg Lauterbach, a famous botanist who led several expeditions to German New Guinea (north- ern PNG). He visited the Ramu River in both 1896 and 1899 (van Steenis Kruseman 1959), which is likely when this specimen was collected.

The majority of the KFRS sawfish specimens (i.e. 35 out of 48 presumed rostra) are no longer present in this collection and must be considered lost. They are still included in Table 2 as they represent important geographical and temporal records. Although the identification of the lost specimens cannot be confirmed, much of the collection was either collected or examined by W. Filewood in the 1960s and 1970s and thus identifications can be considered relatively accurate. Excluding the lost specimens, a total of $3 \mathrm{~A}$. cuspidata, 1 P. clavata, $32 P$. pristis and $3 P$. zijsron were recorded in collections (Table 2). A number of the specimens were collected from locations where sawfish had not been previously recorded, e.g. Nigoherm Islands (Manus Province), Warangoi River (East New Britain), Aiome (Ramu River), Seeadler Harbour (Manus Island) and Balimo (Fly River delta).

\section{DISCUSSION}

\section{Cultural significance}

Sawfish hold cultural significance in various parts of PNG. Villagers along the Sepik River are said to believe that sawfish spirits 'will punish people who break fishing taboos by unleashing destructive rainstorms' (McDavitt 1996). Some Iatmul clans in the Middle Sepik River use sawfish rostra as a totem and decorated rostra form part of dance costumes. One such example of a decorated rostrum, deposited in Museum Victoria in Australia (Item X 32276), is a painted Pristis pristis rostrum collected from the Middle Sepik River in 1920 (Fig. 2). Another example is a

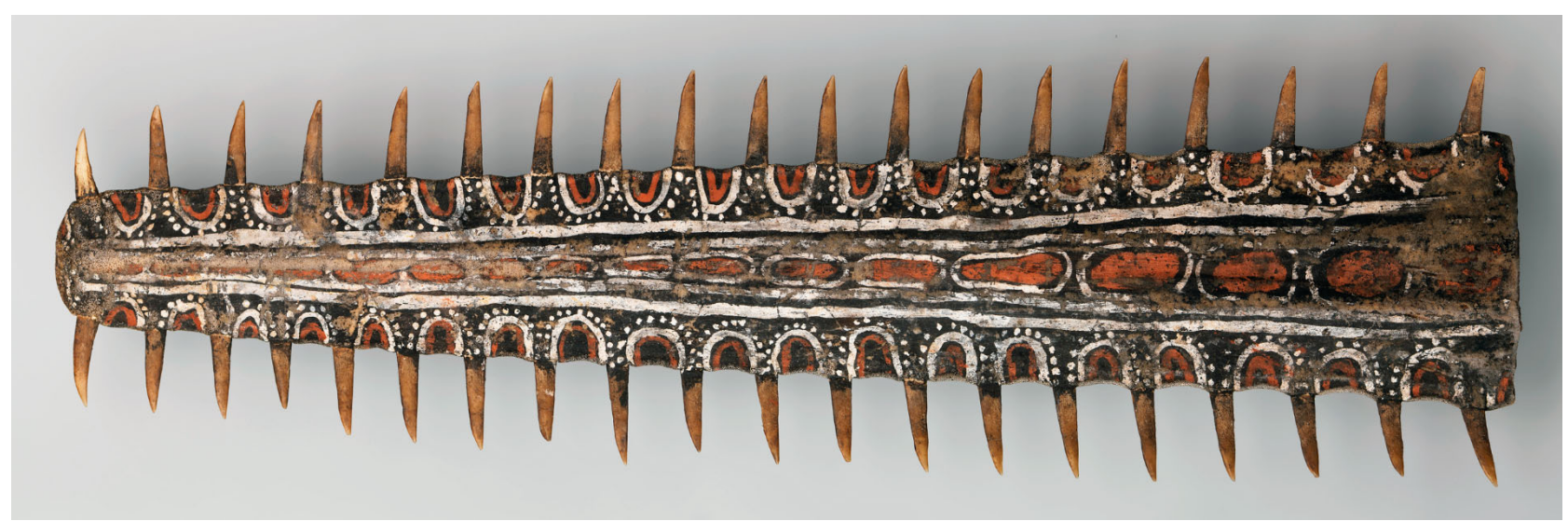

Fig. 2. Painted sawfish rostrum; part of a mask costume. Iatmul, Middle Sepik, Papua New Guinea. Acquired between 1915 and 1920. Australian War Museum Collection, on loan. Source Museum Victoria (X32276). Photograph by Jon Augier 


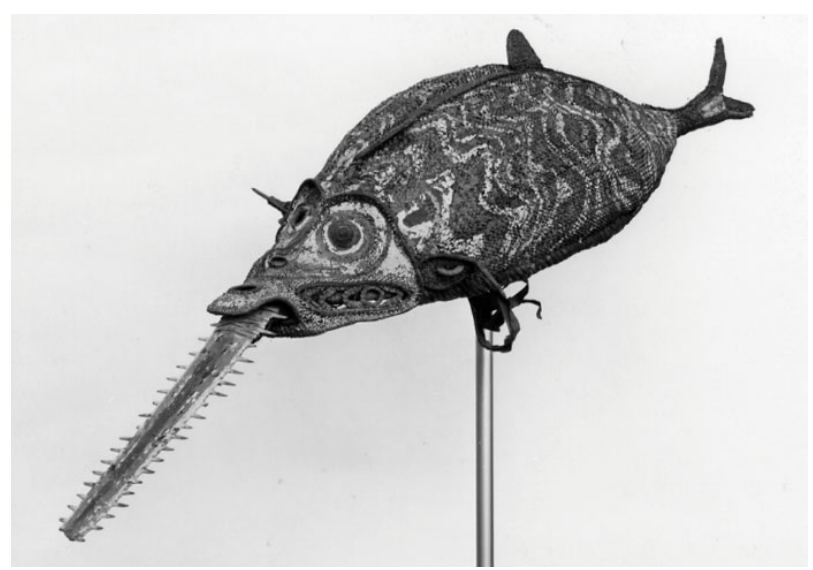

Fig. 3. Decorated rostrum which has been incorporated into a dance mask, deposited in the Ethnologisches Museum der Staatlichen Museen zu Berlin (Tanzmaske - Ident. Nr. VI 48057). Photo: Ethnologisches Museum Staatliche Museen zu Berlin

decorated rostrum which has been incorporated into a dance mask, housed at the Ethnologisches Museum der Staatlichen Museen zu Berlin (Tanzmaske Ident. Nr. VI 48057) (Fig. 3). Sawfish are depicted on carvings in some locations, particularly in the Sepik River where sawfish heads are sometimes carved on shields (e.g. www.art-pacific.com/artifacts/nuguinea /shields/shieldso.htm) and masks (e.g. www.art-pacific. com/artifacts/nuguinea/sepikriv/sepiklow/sepiklow. $\mathrm{htm})$. Sawfish rostra have also been used as weapons in PNG (McDavitt 1996). There are several records of swords made out of sawfish rostra where the base is cut down to form a handle (see Fig. 162 in Cowper 1906). Two similar such swords are also in the McGregor collection of the University of Aberdeen's Human Culture Collection (registration ABDUA 57939).

\section{Evidence of declines in sawfish populations in PNG}

The first indication of declines in sawfish in PNG was documented in Burton (1995), during an interview with the Mipan villagers in the Middle Fly River in March 1994. The interviewees stated that sawfish (local name 'katoga') are now absent from the area, which they attributed to overfishing, possibly from cross-border fishers. Swales (2002) reported that $P$. pristis is less frequently caught in main channel sites of the Upper and Middle Fly River. Storey et al. (2009) reported that although $P$. pristis was once common in the Middle Fly, it has not been seen upstream of Everill Junction for at least 15 yr. In contrast, it was still common downstream of Everill Junction and also in the Strickland River. Everill Junction is a major point of dilution for the mining run-off coming from the Ok Tedi mine site (see below), thus it is possible that sawfish are avoiding the areas upstream in the Middle Fly (Storey et al. 2009). However, increased gillnetting in the Middle Fly by local villagers and possibly Indonesian refugees is likely a major reason for these declines.

The Ok Tedi mine is one of the largest copper mines in the world and commenced operations in 1984. Due to the high rainfall in the area of operation, it is not possible to construct tailings dams; thus tailings and waste rock are discharged into the local waterways which feed into the Fly River system (Swales et al. 2000). This has led to increased riverbed aggradation resulting in the loss of habitat for fish. This, combined with elevated levels of dissolved and particulate copper from mining activities, has possibly affected sawfish in the Upper and Middle Fly River. Increase aggradation of the riverbed of up to $3 \mathrm{~m}$ in the Middle Fly River has likely also affected the prey items of $P$. pristis, including freshwater prawns Macrobrachium spp. (Storey et al. 2000).

In Lake Murray, Taniuchi et al. (1991) caught $23 P$. pristis over a week-long period in 1989, but the species has not been seen in that area for at least the last 4 yr (G. Barmby pers. comm.). In the Sepik River, Herre (1936) reported sawfish as being common, but despite rostra seen in many villages, Coates (1983a) did not record sawfish in their survey catches and Coates (1987) considered sawfish rare in the Sepik River. However, it is not possible to determine whether there has been a decline in the Sepik River given the lack of substantiated data. Both of these river systems lack an estuary in contrast to the southern PNG rivers, thus limiting critical habitat for sawfish. One of the authors of this paper (R. R. Mana) observed many rostra, some over $1 \mathrm{~m}$ in length, at Marienburg (a Catholic mission close to Imbuando village) in the 1970s, but they have rarely been seen there since the 1980s.

The historical data presented in this study are thus important for highlighting the pre-mining range of sawfish in the Fly and other systems in PNG.

\section{Size information}

Last \& Stevens (2009) reported that A. cuspidata attains lengths of $3500 \mathrm{~mm} \mathrm{TL}$, with records of $6000 \mathrm{~mm}$ TL doubtful. Two specimens were recorded in this study with estimated lengths exceeding $4000 \mathrm{~mm}$ TL $(\sim 4100$ and $\sim 4480 \mathrm{~mm} \mathrm{TL})$. Likewise, 
Last \& Stevens (2009) stated that $P$. zijsron can attain lengths of at least $5300 \mathrm{~mm} \mathrm{TL}$, but was reported to have reached at least $7300 \mathrm{~mm}$ TL. Thus, the record of a $\sim 6420 \mathrm{~mm}$ TL individual in this study represents one of the largest specimens recorded for this species. Pristis clavata was reported to attain lengths of $3100 \mathrm{~mm}$ TL (Last \& Stevens 2009), close to the $\sim 3030 \mathrm{~mm}$ TL individual recorded in this study. Although these estimates must be treated with caution (as they are based on fin measurements), it is interesting to note that for 3 of the 4 species of sawfish, very large individuals close to the maximum known sizes are still present in PNG waters.

\section{Positive news for sawfish in PNG}

Although there appear to have been documented declines of sawfish in some parts of PNG, it is not all bad news. The huge delta regions in the Gulf of Papua, e.g. Purari-Kikori and Fly, provide an expansive area of suitable habitat for sawfish in combination with a relatively low human population, and thus low overall fishing pressure. The recording of all 4 species of sawfish in artisanal catches during a weeklong survey to Daru and Katatai (Western Province) in October 2014 provides evidence that the species are still common in that area, despite this being more heavily fished than much of the Gulf of Papua inshore region. Recent surveys also highlighted that $P$. clavata is still present, even though it had been considered possibly extinct from PNG (Dulvy et al. 2016). While that species once had a wide range in the Indo-West Pacific (Dulvy et al. 2016), the PNG observations in fact represent the only recent records of the species outside of Australia.

Jenkins (2000) reported possibly unharvested populations of $P$. pristis in Lake Lalili in West New Britain. They could also be distributed widely throughout the rivers of West New Britain. Sport fishers from the Baia Lodge in West New Britain reported seeing sawfish near river mouths leading up to the new moon between May and November, just before baitfish enter the rivers (R. Reimann pers. comm.). The southern coast of New Britain is poorly surveyed and could also represent an important area for sawfish.

Northern Australia is considered to be the last stronghold for the 4 species of sawfish that occur in the Indo-Pacific (Phillips et al. 2011, Dulvy et al. 2016). A detailed investigation into the current status of sawfish in PNG is urgently required to determine whether PNG may also be a stronghold for one or more sawfish species, not only regionally, but globally.

\section{CONCLUSIONS}

The information compiled and produced in this study provides a strong baseline from which more detailed studies of the status of sawfish in PNG can be undertaken. This study highlighted a number of critical areas for sawfish in PNG, in particular the Purari-Kikori delta system, Fly and Strickland Rivers (including Lake Murray), Western Province coastal areas (Katatai to mouth of Bensbach), Sepik and Ramu Rivers, Bougainville and West New Britain. These critical areas need to be thoroughly surveyed to determine the abundance and exploitation of sawfish in those areas. Obtaining detailed information on the cultural and socioeconomic value of sawfish to local communities is also paramount. Furthermore, improving the capacity for PNG researchers to develop and maintain a focused research effort on sawfishes will be crucial. Realising these aims will benefit the implementation of a global strategy for sawfish conservation (Harrison \& Dulvy 2014).

Acknowledgements. The current PNG shark and ray biodiversity project was funded by the Australian Centre for International Agricultural Research (ACIAR), PNG National Fisheries Authority (NFA) and the Commonwealth Scientific Industrial Research Organisation (CSIRO). Thanks go to Chris Barlow and Jes Sammut (ACIAR), Leban Gisawa, Brian Kumasi, Luanah Yaman, Thomas Usu and Leontine Baje (NFA), and Daniel Gledhill and David Smith (CSIRO) for their support. The authors thank the following museum staff for providing access to sawfish specimens and assistance during visits or by email: Mark McGrouther (AMS), Jeff Johnson (QM), Alastair Graham and John Pogonoski (CSIRO), Jeff Williams (USNM), Alfred Ko'ou (UPNG), Ralf Thiel, Matthias Stehmann and Simon Weigmann (ZMH), Peter Bartsch (ZMB), and Dave Catania (CAS). We thank the following people for their assistance in the field: Benthly Sabub, Rickson Lis and Kevin Atana (NFA), Jonathan Smart (JCU) and Simon Vieira (doMar Research). We thank the fishers of the prawn trawl vessels and special thanks to the NFA on-board fisheries observers who collected data and tissue samples for sharks and rays. We gratefully acknowledge the input and assistance of the people at the various villages and buyers at the locations visited, in particular the village of Katatai in Western Province, Philamarine fish buyer in Daru, United Seafoods fish buyer in Port Moresby and AsiaPac fish buyer in Alotau; without their assistance and willingness to provide information and data, we could not have collected so much valuable data. We also thank Louise Conboy (CSIRO) for assistance with genetic identification of the contemporary fin samples; Madeline Green (UTas, CSIRO) for reviewing and commenting on an earlier draft of the manuscript; Museum Victoria for allowing use of the decorated rostrum image; Garry Barmby (Angling Adventures), Garrick Hitchcock (Arafura Consulting), Ray Moore (retired), Riccard Reimann (Baia Sportsfishing), and Christian Döehler and Nicholas Evans (ANU) for providing important anecdotal or historical information; Hans Paepke, Hans-Ulrich Raake and Johanna Kapp (ZMB) for providing 
collection information for the oldest PNG sawfish specimens; and Dean Grubbs (Florida State University) and Gregg Poulakis (Florida Fish and Wildlife Conservation Commission) for organising the special sawfish issue and symposium at the American Elasmobranch Society Conference 2016. P.M.K. was supported by the Marine Biodiversity Hub, a collaborative partnership supported through funding from the Australian Government's National Environmental Science Program (NESP).

\section{LITERATURE CITED}

Allen GR, Coates D (1990) An ichthyological survey of the Sepik River, Papua New Guinea. Rec Aust Mus Suppl 34: 31-116

Allen GR, Parenti LR, Coates D (1992) Fishes of the Ramu River, Papua New Guinea. Ichthyol Explor Freshwat 3: 289-304

Anas A, Kumoru L, Lokani P (2000) Status of coral reef fisheries: statistics, fishing-gears and impacts. In: Munday PL (ed) The status of coral reefs in Papua New Guinea. Global Coral Reef Monitoring Network (GCRMN) Report, Port Moresby

Aufenanger H (1970) Myths and beliefs from prehistoric times at the Lower Sepik River, New Guinea. Asian Ethnol 29:133-175

Berra TM, Moore R, Reynolds LF (1975) The freshwater fishes of the Laloki River system of New Guinea. Copeia 1975:316-326

Burton J (1995) Middle Fly and north Morehead area study. Ok-Fly Social Monitoring Project Report No. 10. Pacific Social Mapping, Canberra

Chapau MR, Opnai JL (1983) Shark fishery of the Gulf of Papua. Report 83-09, Fisheries Research and Surveys Branch, Department of Primary Industries, Port Moresby

Coates D (1983a) Notes on miscellaneous fish species from the Sepik River, roundwaters and floodplain. Report 8312, Fisheries Research and Surveys Branch, Department of Primary Industries, Port Moresby

Coates D (1983b) Raw data and preliminary analysis of gillnet catches from the Sepik River, roundwaters and floodplain. Report 83-16, Fisheries Research and Surveys Branch, Department of Primary Industries, Port Moresby

Coates D (1987) Consideration of fish introductions into the Sepik River, Papua New Guinea. Aquacult Fish Manage 18:231-241

Coates D (1993) Fish ecology and management of the SepikRamu, New Guinea, a large contemporary tropical river basin. Environ Biol Fishes 38:345-368

Cowper HS (1906) The art of attack. Being a study in the development of weapons and appliances of offence, from the earliest times to the age of gunpowder. W Holmes Printers, London

Dept of Agriculture, Stock and Fisheries (1972) Ramu River survey. Unpublished report, Department of Agriculture, Stock and Fisheries, Port Moresby

Dept of Agriculture, Stock and Fisheries (1973) Report on a fisheries survey of the coastal area from Sigabadu village, 45 miles W of Daru, to the West Irian border. Unpublished report, Department of Agriculture, Stock and Fisheries, Port Moresby

Dulvy NK, Fowler SL, Musick JA, Cavanagh RD and others (2014) Extinction risk and conservation of the world's sharks and rays. eLife 3:e00590
* Dulvy NK, Davidson LNK, Kyne PM, Simpfendorfer CA, Harrison LR, Carlson JK, Fordham SV (2016) Ghosts of the coast: global extinction risk and conservation of sawfishes. Aquat Conserv 26:134-153

Evans CR, Opnai LJ, Kare BD (1995) Research and management of the industrial prawn fishery of the Gulf of Papua. South Pacific Commission SPC/FAA workshop on the management of South Pacific inshore fisheries, 26 June to 7 July 1995, Noumea, New Caledonia

F Faria VV, McDavitt MT, Charvet P, Wiley TR, Simpfendorfer CA, Naylor GJP (2013) Species delineation and global population structure of Critically Endangered sawfishes (Pristidae). Zool J Linn Soc 167:136-164

Filewood LWC (1973) Guide to elasmobranch key, with notes on collection of data. Unpublished report, Department of Primary Industries and Fisheries, Port Moresby

Fricke R, Eschmeyer WN (2016) Guide to fish collections. http://researcharchive.calacademy.org/research/ichthyo logy/catalog/collections.asp (accessed 9 Aug 2016)

Frielink AB Jr (1983) A socio-economic study of the artisanal fisheries in the delta of the Gulf Province Papua New Guinea. Report 83-12, Fisheries Research and Surveys Branch, Department of Primary Industries, Port Moresby

Glucksman J (1969) Preliminary survey, Lake Murray, 24$29^{\text {th }}$ November, 1969. Unpublished report, Department of Agriculture, Stocks and Fisheries, Konedobu

Haines AK (1977) Fish and fisheries of the Purari River and delta. In: Purari River (Wabo) Hydroelectric Scheme Environmental Studies, Vol 1. Office of Environment and Conservation and the Department of Minerals and Energy, Konedobu

Haines AK (1978/1979) The subsistence fishery of the Purari Delta. Sci New Guinea 6:80-95

Haines AK (1979) An ecological survey of the Lower Purari River System, Papua New Guinea. In: Purari River (Wabo) Hydroelectric Scheme Environmental Studies, Vol. 6. Office of Environment and Conservation, Waigani and Department of Minerals and Energy, Konedobu

Haines AK, Stevens RN (1983) Subsistence and coastal fisheries. In: Petr T (ed) The Purari - tropical environment of a high rainfall river basin. Dr W Junk Publishers, The Hague, p 385-408

Harrison LR, Dulvy NK (eds) (2014) Sawfish: a global strategy for conservation. IUCN Species Survival Commission's Shark Specialist Group, Vancouver

Herre AWCT (1936) Fishes of the Crane Pacific expedition. Field Museum of Natural History Zoology Series, Vol 21. Field Museum Press, Chicago

Hinton A (1967) Fisheries survey-Kemp Welch River. Unpublished report, Division of Fisheries, Konedobu

Hitchcock G (2002) Fish fauna of the Bensbach River, southwest Papua New Guinea. Mem Queensl Mus 48:119-122

Hitchcock G (2004) Wildlife is our gold: political ecology of the Torassi River borderland, southwest Papua New Guinea. PhD thesis, The University of Queensland, Brisbane

Hyslop EJ (1996) Species composition of the fish catch of the Angabanga River, Papua New Guinea. Sci New Guinea 22:3-8

Ishihara H, Taniuchi T, Shimizu M (1991) Sexual dimorphism in number of rostral teeth in the sawfish, Pristis microdon collected from Australia and Papua New Guinea. Univ Mus Univ Tokyo Nat Cult 3:83-89

IUCN (2016) The IUCN Red List of Threatened Species, version 2016.1. www.iucnredlist.org (accessed 8 August 2016) 
Jenkins A (2000) Training in survey of coastal wetlands at Collingwood Bay, Papua New Guinea (location changed to Kimbe Bay, Papua New Guinea). Wetlands International-Oceania, Canberra. www.ramsar.org/news/report -on-evian-training-programme-in-papua-new-guinea

Kyne PM, Simpfendorfer CA (2014) Eastern Indian and Western Central Pacific Ocean. In: Harrison LR, Dulvy NK (eds) Sawfish: a global strategy for conservation. IUCN Species Survival Commission's Shark Specialist Group, Vancouver, p 64-65

Last PR, Stevens JD (2009) Sharks and rays of Australia, 2nd edn. CSIRO Publishing, Collingwood

Liviko I (2012) Gulf of Papua prawn fishery. 2012 Status Report, National Fisheries Authority, Port Moresby

Loop PNG (2015) Fishing duo stunned by 'sea creature'. www.pina.com.fj/?p=pacnews\&m=read\& $o=11069763875$ 574ea0ad113b91c65c1

McDavitt MT (1996) The cultural and economic importance of sawfishes (Family Pristidae). Shark News 8:10-11

Mizue K, Hara M (1991) The rectal gland of freshwater sawfish, Pristis microdon, and bull shark, Carcharhinus leucas, collected from the Daly and Sepik River. Univ Mus Univ Tokyo Nat Cult 3:63-69

Munro ISR (1958) The fishes of the New Guinea region. Papua New Guinea Agr J 10:97-369

Munro ISR (1964) Additions to the fish fauna of New Guinea. Papua New Guinea Agr J 16:141-186

Munro ISR (1967) The fishes of New Guinea. Department of Agriculture, Stock and Fisheries, Port Moresby

Osborne PL (ed) (1987) A draft inventory of wetlands in Papua New Guinea. Department of Environment and Conservation, Boroko

Phillips NM, Chaplin JA, Morgan DL, Peverell SC (2011) Population genetic structure and genetic diversity of three critically endangered Pristis sawfishes in Australian waters. Mar Biol 158:903-915

Powell JH, Powell RE (1999) The freshwater ichthyofauna of Bougainville Island, Papua New Guinea. Pac Sci 53: 346-356

Rapson AM (1955) Survey of fishing potentialities of the Coral Sea and southern and eastern Papua in 1955. Papua New Guinea Agr J 10:31-42

Rapson AM, McIntosh CR (1971) Prawn surveys in Papua and New Guinea. Biological Series 10/5, Department of Agriculture, Stock and Fisheries, Port Moresby

Roberts TR (1978) An ichthyological survey of the Fly River in Papua New Guinea with descriptions of new species. Smithson Contrib Zool 281:1-72

Smith REW, Bakowa KE (1994) Utilisation of floodplain water bodies by the fishes of the Fly River, Papua New Guinea. In: Dudgeon D, Lam PKS (eds) Inland waters of tropical Asia and Australia: conservation and management. Mitt Int Ver Theor Angew Limnol 24:187-196

Smith REW, Hortle KG (1991) Assessment and prediction of the impacts of the Ok Tedi copper mine on fish catches in the Fly River system, Papua New Guinea. Environ Monit Assess 18:41-68

Stevens JD, Pillans RD, Salini J (2005) Conservation assessment of Glyphis sp. A (speartooth shark), Glyphis sp. C (northern river shark), Pristis microdon (freshwater sawfish) and Pristis zijsron (green sawfish). Final Report to

Editorial responsibility: Dean Grubbs (Guest Editor), St. Teresa, Florida, USA the Department of the Environment and Heritage, CSIRO Marine Research, Hobart

Stewart C (1990) Report on the laws relating to gillnet and driftnet fishing in Papua New Guinea. Working paper no. 25, Papua New Guinea Law Reform Commission, Boroko

Storey AW, Tenakanai CD, Bakowa KA, Maie AY, Swales S, Short JW (2000) Distribution and reproductive strategies of Macrobrachium prawns (Decapoda, Caridea, Palaemonidae) in the Fly River system, Papua New Guinea, with observations on possible mining impacts. Verh Int Ver Limnol 27:1-10

Storey AW, Yarrao M, Tenakanai C, Figa B, Lynas J (2009) Use of changes in fish assemblages in the Fly River System, Papua New Guinea, to assess effects of the Ok Tedi copper mine. In: Bolton B (ed) Developments in earth \& environmental sciences, Vol 9. Elsevier, Burlington, MA, p 427-462

Swales S (2002) Fish and fisheries of the Fly River, Papua New Guinea: population changes associated with natural and anthropogenic factors and lessons to be learned. In: Blue millennium: managing global fisheries for biodiversity. Proceedings of UNEP/IDRC thematic workshop, 25-27 June 2001, Victoria

Swales S, Storey AW, Roderick ID, Figa BS (1999) Fishes of the floodplain habitats of the Fly River system, Papua New Guinea, and changes associated with El Niño droughts and algal blooms. Environ Biol Fishes 54: 389-404

Swales S, Storey AW, Bakowa KA (2000) Temporal and spatial variations in fish catches in the Fly River system in Papua New Guinea and the possible effects of the Ok Tedi copper mine. Environ Biol Fishes 57:75-95

Tanaka S (1991) Age estimation of freshwater sawfish and sharks in northern Australia and Papua New Guinea. Univ Mus Univ Tokyo Nat Cult 3:71-82

Taniuchi T, Shimizu M (1991) Elasmobranchs collected from seven river systems in northern Australia and Papua New Guinea. Univ Mus Univ Tokyo Nat Cult 3:3-10

Taniuchi T, Kan TT, Tanaka S, Otake T (1991) Collection and measurement data and diagnostic characters of elasmobranchs collected from three river systems in Papua New Guinea. Univ Mus Univ Tokyo Nat Cult 3:27-41

van Steenis Kruseman MJ (1959) Cyclopaedia of collectors. In: Flora Malesiana Ser 1. www.nationaalherbarium.nl/ FMCollectors/L/LauterbachCAG.htm (accessed 12 Aug 2016)

Wallace JH (1967) The batoid fishes of the east coast of southern Africa. Part I: Sawfishes and guitarfishes. Investig Rep Oceanogr Res Inst 16:1-32

Watabe S (1991) Electrophoretic analyses of freshwater elasmobranchs from northern Australia and Papua New Guinea. Univ Mus Univ Tokyo Nat Cult 3:103-109

* White WT, Appleyard SA, Sabub B, Kyne PM and others (2015) Rediscovery of the threatened river sharks, Glyphis garricki and G. glyphis, in Papua New Guinea. PLOS ONE 10:e0140075

Whitty JM, Phillips NM, Thorburn DC, Simpfendorfer CA, Field I, Peverell SC, Morgan DL (2014) Utility of rostra in the identification of Australian sawfishes (Chondrichthyes: Pristidae). Aquat Conserv 24:791-804

Submitted: August 26, 2016; Accepted: January 5, 2017 Proofs received from author(s): February 27, 2017 